\title{
The Effect of Surgical Stress on Serum Prostate Specific Antigen Level
}

\author{
Mehmet Karabakan1, Binhan Kağan Aktaş², Süleyman Bulut², Cevdet Serkan Gökkaya², Cüneyt Özden², \\ Mehmet Murat Baykam², Ali Memiş² \\ ${ }^{1}$ Clinic of Urology, Erzincan University Megücek Gazi Training and Research Hospital, Erzincan, Turkey \\ ${ }^{2}$ Clinic of Urology, Ankara Numune Training and Research Hospital, Ankara, Turkey
}

\section{ABSTRACT}

Objective: Invasive surgical interventions creating acute stress may give rise to immunological and hormonal disturbances in patients undergoing surgery. Previous studies reported elevations in serum prostate-specific antigen (PSA) level following coronary bypass and myocardial infarction. The current study aims to investigate the effect of surgical stress on serum PSA level.

Methods: Thirty-three patients who underwent open renal stone surgery, without any known infectious prostatic disorder or prostate cancer that may elevate serum PSA level, were included in the study. In all patients, serum levels of total and free PSA (tPSA and fPSA), follicle-stimulating hormone $(F S H)$, luteinizing hormone $(\mathrm{LH})$, total and free testosterone, C-reactive protein (CRP), fibrinogen, albumin, and ferritin and erythrocyte sedimentation rate (ESR) were measured both at baseline and post-operative day 3. Wilcoxon signed-rank test was used for the statistical analysis.

Results: The mean age of patients was $53.9 \pm 8$ (40-66). The mean baseline and post-operative levels of the measured serum parameters are given in Table 1. All of them differed significantly between baseline and post-operative day 3, except for LH, tPSA, and fPSA. CRP, fibrinogen, ferritin, and ESR are known as acute phase reactants of the post-operative endocrine response. However, serum total and free testosterone levels, albumin, and FSH decreased on the contrary acute phase reactants in the present study.

Conclusion: According to our results, serum PSA level was not affected by acute surgical stress. (JAREM 2015; 5: 22-4)

Keywords: Surgical stress, PSA, testosterone

\section{INTRODUCTION}

Prostate-specific antigen (PSA) is a serine protease from the family of human tissue kallikreins localized on the short arm of chromosome 19 (19q13.4), and its physiological function involves the liquefaction of seminal coagulum (1). PSA (Human kallikrein 3) is primarily expressed in the prostate acinar cells and ductal epithelium under androgen regulation (2-4). Its occurrence rate in semen is approximately 100 times higher than in serum $(2,3)$. PSA normally exists in the blood of men at low rates $(<4 \mathrm{ng} / \mathrm{mL})$, and it is mostly bound with protease inhibitors, except a small amount in the free form of serum PSA (fPSA) (2).

Although PSA was first defined in the prostate in serum in 1970 (5) and in seminal plasma in 1971 (6), PSA purification in the prostate tissue was first performed in 1979 (7). PSA measurement in serum was performed in 1980 for the first time (8), and the approval from the Food \& Drug Administration (FDA) was received for its use in monitoring prostate cancer in 1986.

Although PSA was initially thought to be a specific marker peculiar to the males, it was demonstrated in the later studies that it was upregulated by steroid hormones in non-prostatic tissues both in males and females (3).

Subsequently, Bruchovsky and Wilson demonstrated dihydrotestosterone (DHT) as the main androgen in the prostate. They revealed that the prostate could be reduced without any decrease in the peripheral testosterone level; thus, finasteride therapy was developed (1).
In some studies conducted to determine the effect of surgical stress on serum testosterone and PSA levels, there is some evidence that stress affects the secretion of some sexual hormones $(9,10)$. Immunological and hormonal changes in patients are seen with invasive interventions that can lead to acute stress $(9,11,12)$.

In a study conducted on rats, it was found that there was a decrease in serum testosterone levels because of the stress that occurred after surgical intervention (9). In another recent study, PSA measurements of 24 patients who underwent coronary bypass were performed during the first 6 days, and a statistically significant increase was observed in total PSA (tPSA) levels (13). In some studies, it was detected that cardiovascular stress occurring after cardiovascular diseases such as cardiopulmonary bypass and myocardial infarction could cause fluctuations in PSA levels (14).

In our study, the effect of surgical stress on early serum testosterone and PSA levels and the relationship between them were evaluated.

\section{METHODS}

The study included 33 patients who underwent open renal stone surgery, who did not have any moderate or severe lower urinary tract symptoms, and who did not undergo urethral catheterization. Patients who used 5 alpha-reductase inhibitor and/or testosterone preparations or other hormonal drugs; had a history of urogenital system malignancy, prostate surgery, cystectomy, or 
Table 1. Preoperative and postoperative data

\begin{tabular}{l|c|c|c|}
\hline & Preoperative & Post-operative & ${ }^{*} \mathbf{p}$ \\
\hline tPSA & $1.4 \pm 2.1$ & $1.6 \pm 2$ & 0.561 \\
\hline fPSA & $0.46 \pm 0.61$ & $0.41 \pm 0.43$ & 0.486 \\
\hline f-testosterone & $7.43 \pm 3.12$ & $5.78 \pm 3.02$ & 0.010 \\
\hline t-testosterone & $3.29 \pm 1.37$ & $2.49 \pm 1.47$ & 0.006 \\
\hline LH & $5.76 \pm 3.34$ & $6.11 \pm 3.19$ & 0.531 \\
\hline FSH & $7.32 \pm 5.25$ & $7.01 \pm 6.44$ & 0.004 \\
\hline CRP & $3.6 \pm 4.44$ & $26.07 \pm 45.83$ & $<0.001$ \\
\hline Fibrinogen & $372.31 \pm 110.29$ & $528.57 \pm 142.20$ & $<0.001$ \\
\hline Ferritin & $83.37 \pm 64.00$ & $172.48 \pm 146.91$ & $<0.001$ \\
\hline $\begin{array}{l}\text { ESR } \\
\text { Albumin }\end{array}$ & $12.97 \pm 19.36$ & $26.20 \pm 24.62$ & 0.001 \\
\hline $\begin{array}{l}\text { Alb.24 } \pm 6.54 \\
\text { *Wilcoxon signed-ranks test, } \mathrm{p}<0.05 \text { was evaluated as significant. }\end{array}$ \\
$\begin{array}{l}\text { tPSA: total PSA; fPSA: free PSA; f-testosterone: free testosterone; } \\
\text { t-testosterone: total testosterone; } \text { LH: luteinizing hormone; FSH: } \\
\text { follicle stimulating hormone; CRP: C-reactive protein; ESR: erythrocyte } \\
\text { sedimentation rate }\end{array}$
\end{tabular}

another pelvic surgery; and underwent prostate biopsy or colonoscopy due to any reason were excluded from the study. Of patients with high PSA levels, the ones whose prostate biopsy pathology was found to be benign were included in the study.

For all patients, fPSA and tPSA levels on the preoperative and postoperative $3^{\text {rd }}$ day, serum luteinizing hormone $(\mathrm{LH})$, follicle stimulating hormone (FSH), $\mathrm{f}$ - and t-testosterone, C-reactive protein (CRP), sedimentation, fibrinogen, albumin, and ferritin levels were evaluated.

PSA, fPSA, testosterone, and LH levels of patients were measured using the radioimmunoassay technique with the device of the UniCel ${ }^{\circledR}$ DxI 800 Immunoassay System (Beckman Coulter, Inc. California, USA). Written informed consents were obtained from the patients who participated in the study.

\section{Statistical Analysis}

The data obtained were analyzed using the Statistical Package for the Social Sciences (SPSS) (SPSS, Chicago, IL, USA) version 15.0 software. Preoperative and postoperative values were compared with Wilcoxon signed-ranks test. The value of $p<0.05$ was accepted to be statistically significant.

\section{RESULTS}

The mean age of patients who participated in the study was $53.9 \pm 8(40-66)$ years. The preoperative values were found as follows: tPSA: $1.4 \pm 2.1$ (0.16-9.70), fPSA: $0.46 \pm 0.61$ (0.08-3.19), t-testosterone: $3.29 \pm 1.37(0.76-6.55)$, f-testosterone: $7.43 \pm 3.12$ (0.20-14.80), CRP: $3.6 \pm 4.44$ (0.50-18.00), LH: $5.76 \pm 3.34$ (1.4614.80), and FSH: $7.32 \pm 5.25$ (1.37-25.80). The postoperative values were found as follows: tPSA: $1.6 \pm 2(0.17-7.34)$, fPSA: $0.41 \pm 0.43$ (0.09-2.24), t-testosterone: $2.49 \pm 1.47$ (0.66-6.83), f-testosterone: $5.78 \pm 3.02(0.19-12.00), \quad C R P: 26.07 \pm 45.83(0.70-212.00), \quad L H:$ 6.11 \pm 3.19 (1.96-16.60), and FSH: $7.01 \pm 6.44(0.08-30.00)$.

In the evaluation of the results, an increase in tPSA levels and a decrease in fPSA levels were observed in the early period af- ter surgical stress. However, the differences were statistically insignificant. A statistically significant change was detected in t-testosterone and $f$-testosterone levels $(p=0.006$ and $p=0.010$, respectively). There was an increase in serum $\mathrm{LH}$ levels, but it was not statistically significant (Table 1).

Although a significant increase was detected in CRP, fibrinogen, ferritin, and sedimentation levels, which are known as acute phase reactants in acute endocrine response after surgical intervention, a significant decrease was observed in serum albumin levels.

\section{DISCUSSION}

During stress response to trauma and surgery, various endocrine, metabolic, and immunological changes occur. This response and reaction is found as a series of autonomous, neuroendocrine, and metabolic responses. Stimuli from the surgical site activate the hypothalamic-pituitary hormone secretion and sympathetic system. Although they increase the release of catabolic hormones such as cortisol and catecholamines, they decrease the release of anabolic hormones such as insulin and testosterone (10). LH is secreted from the anterior pituitary by gonadotropins (15), and it plays a role in the release of testosterone from the interstitial Leydig cells of the testicle.

In the study of Janson et al. (11) that was conducted on students, it was demonstrated that a decrease in serum LH levels was observed with exam stress. Almeida et al. (16) found that the stress resulting from immobilization for $6 \mathrm{~h}$ in a day decreased serum LH levels by $29 \%$ and testosterone levels by $37 \%$ in Wistar rats during 60 days. Moreover, in the study conducted by Hajime et al. (12), it was revealed that testosterone levels decreased in males under stress.

Ahmad et al. (9) performed a study on rats. They found that although a significant decrease was detected in serum $\mathrm{LH}$ and testosterone levels measured at the end of the $1^{\text {st }}$ and $2^{\text {nd }}$ weeks after surgical stress, serum testosterone levels decreased to the lowest level at the end of the $2^{\text {nd }}$ week in which surgical procedure was administered. On the other hand, Woolf et al. (17) detected a statistically significant decrease in testosterone and LH levels after stress. In our study, a significant decrease was observed in testosterone levels in the measurements performed on the $3^{\text {rd }}$ day after surgical stress, which was consistent with the literature. However, even if not significant, an increase was detected in serum LH levels.

After testosterone enters into the prostate cell, it is converted into DHT by 5 alpha-reductase, which is a nuclear enzyme. DHT binds to the androgen receptor (AR). Following the activation of the $T+A R$ complex, PSA leads to biological behaviors such as prostatic alkaline phosphatase (PAP), secretion of growth factors, and apoptosis (15). It is known that prostatic epithelial cells enter into apoptosis in the presence of decreased androgen levels (18).

According to the study of Hassan et al. (19), surgical stress prevented prostatic apoptosis and delayed prostatic involution in rats administered with androgen ablation. One of the important points is the effect of testosterone replacement treatment (TRT) on PSA levels. It was found that TRT caused minimal PSA increase $(20,21)$. However, in a systematic study conducted by Shabsigh et 
al. (22), they stated that TRT did not cause a significant increase in the serum PSA levels.

Based on these studies, it is understood that the testosterone level affects the PSA level. Although the level of t-testosterone decreased significantly in our study, no significant change was detected in PSA levels.

In the study of Ahmad et al. (9), a higher rate of decrease in testosterone levels was detected at the end of the $2^{\text {nd }}$ week after surgical stress than the level measured at the end of the $1^{\text {st }}$ week. This suggested that a PSA change associated with the change in the testosterone level occurred after the $2^{\text {nd }}$ week in our study.

\section{CONCLUSION}

The detection of no change in serum PSA levels despite a significant decrease in testosterone levels in our study shows that PSA cannot be evaluated among acute phase reactants. This suggests that the measurements performed on the postoperative $3^{\text {rd }}$ day are an early period for the detection of PSA changes. Therefore, it is suggested that larger case series are needed for investigating the effect of surgical stress on PSA. Moreover, further studies that will evaluate testosterone and PSA levels both in the early period and in the late period after stress should be conducted.

Ethics Committee Approval: Ethics committee approval was received for this study.

Informed Consent: Written informed consent was obtained from the patients who participated in this study.

Peer-review: Externally peer-reviewed.

Author Contributions: Concept - M.K., C.S.G.; C.S.G. Design - M.K., S.B.; Supervision - A.M., M.M.B.; Resource - M.K., B.K.A.; Materials C.S.G., C.Ö.; Data Collection and/or Processing - B.K.A., C.Ö.; Analysis and/or Interpretation - B.K.A., C.S.G.; Literature Review - M.K., S.B.; Writing - M.K., B.K.A.; Critical Review - A.M., M.M.B.

Conflict of Interest: No conflict of interest was declared by the authors.

Financial Disclosure: The authors declared that this study has received no financial support.

\section{REFERENCES}

1. Bruchovsky N, Wilson JD. The intranuclear binding of testosterone and 5-alphaandrostan-17-beta-ol-3-one by rat prostate. J Biol Chem 1968; 243: 5953-60.

2. Stamey TA, Yang N, Hay AR, Mcneal JE, Freiha FS, Redwine E. Prostate-specific antigen as a serum marker for adenocarcinoma of the prostate. N Engl J Med 1987; 317: 909-16. [CrossRef]
3. Diamandis EP, Yu H. Nonprostatic sources of prostate-specific antigen. Urol Clin North Am 1997; 24: 275-82. [CrossRef]

4. Litman HJ, Bhasin S, O'Leary MP, Link CL, McKinlay JB. An investigation of the relationship between sex-steroid levels and urological symptoms: results from the Boston Area Community Health survey. B J U Int 2007; 100: 321-6. [CrossRef]

5. Ablin RJ, Soanes WA, Bronson P, Witebsky E. Precipitating antigen of the normal human prostate. J Reprod Fertil 1970; 22: 573-4. [CrossRef]

6. Hara M, Koyanagi $Y$, Inoue T, Fukuyama T. Some physicochemical characteristics of gamma seminoprotein, an antigenic component specific for human seminal plasma: forensic immunological study of body fluids and secretion. Nippon Hoigaku Zasshi 1971: 25: 322-4.

7. Wang ML, Valenzuela L, Murphy $G$, et al. Purification of human prostate specific antigen. Invest Urol 1979; 17: 159-63.

8. Kuriyama M, Wang MC, Papsidero LD, et al. Quantitiation of PSA in serum by a sensitive enzyme immunoassay. Cancer Res 1980; 40: 46-58.

9. Ahmad M, Hossein KJ, Faranak D, Elham RK, Mohammad F. Studying the effect of surgery stress on HPG axis hormones. Advances in Environmental Biology 2012; 6: 3092-5.

10. Sabiston. Texbook of surgery $15^{\text {nd }}$ ed. Philadelphia $1997 ; 62-7$.

11. Johansson GG, Laakso ML, Peder M, Karonen SL. Examination stress decreases plasma level of luteinizing hormone in male students. Psychosom Med 1988; 50: 286-94. [CrossRef]

12. Fukui $\mathrm{H}$, Yamashita $\mathrm{M}$. The effect of music and visual stress on testosterone and cortisol in men and women. Neuro Endocrinol Lett 2003; 24: 173-80.

13. Mahfouz RA, Cortas NK, Ibrahim G, Khalife S, Daher RT. Variations in prostate-specific antigen free/total ratio in acute stress. Scand J Clin Lab Invest 2008; 68: 624-7. [CrossRef]

14. Patane S, Marte F. Prostate-specific antigen kallikrein: from prostate cancer to cardiovascular system. Eur Heart J 2009; 30: 1169-70. [CrossRef]

15. Guyton CA, Hall EJ. Medical Physiology, translated by: Farrokh Shadan MD Tchehr CO, 2000, 2.

16. Almeida SA, Petenusci SO, Franci JA, Rosa e Silva AA, Carvalho TL. Chronic immobilization-induced stress increases plasma testosterone and delays testicular maturation in pubertal rats. Andrologia. 2000; 32: 7-11 [CrossRef]

17. Woolf PD, Hamill RW, McDonald JV, Lee LA, Kelly M. Transient hypogonadotropic hypogonadism caused by critical illness. J Clin Endocrinol Metab 1985; 60: 444-50. [CrossRef]

18. Isaacs JT, Lundmo PI, Berges R, Martikainen P, Kyprianou N, English HF. Androgen regulation of programmed death of normal and malignant prostatic cells. J Androl 1992; 13: 457-64.

19. Hassan S, Karpova Y, Flores A, D'Agostino R Jr, Kulik G. Surgical stress delays prostate involution in mice. PLoS One 2013; 8 : e78175. [CrossRef]

20. Gerstenbluth RE, Maniam PN, Corty EW, Seftel AD. Prostate-specific antigen changes in hypogonadal men treated with testosterone replacement. J Androl 2002; 23: 922-6.

21. McLaren D, Siemens DR, Izard J, Black A, Morales A. Clinical practice experience with testosterone treatment in men with testosterone deficiency syndrome. BJU International 2008; 102: 1142-6. [CrossRef]

22. Shabsigh R, Crawford ED, Nehra A, Slawin KM. Testosterone therapy in hypogonadal men and potential prostate cancer risk: a systematic review. Int J Impot Res 2009; 21: 9-23. [CrossRef] 